\title{
Digestibility and Metabolism of Young Cattle in Yakutia after Inclusion of Non-Conventional
} Feed Additives in their Diet

\section{Nataliya M. CHERNOGRADSKAYA}

Ph.D. (in Agricultural Sciences)

Associate Professor

Department of General Zootechnics

Yakut State Agricultural Academy

3, Sergelyakhskiy Highway, Yakutsk, 677007, Russian Federation

\section{Mikhail F. GRIGOREV}

Ph.D. (in Agricultural Sciences)

Associate Professor

Department of General Zootechnics

Yakut State Agricultural Academy

3, Sergelyakhskiy Highway, Yakutsk, 677007, Russian Federation

grig_mf@mail.ru

Alexandra I. GRIGOREVA

Senior Lecturer

Department of Higher Mathematics

North-Eastern Federal University

48, Kulakovskiy Str., Yakutsk, 677013, Russian Federation

\section{Zinaida G. TATARINOVA}

Ph.D. (in Veterinary Sciences)

Associate Professor

Department of Veterinary Sanitary Expertise and Hygiene

Yakut State Agricultural Academy

3, Sergelyakhskiy Highway, Yakutsk, 677007, Russian Federation

$$
\text { 7(924)5980860 }
$$

\section{Abstract}

The article presents the results of research which aim was to to determine the impact of local nontraditional fodder additives (zeolite-hongurine of Honguruu deposit, Suntarsky district, and 
sapropels of the local lake) on the digestibility of fodder, as well as the metabolism of young cattle in Yakutia. To conduct the experiments 3 groups of heifers of Kholmogorsk breed were formed, 10 heads each. The conditions of animals keeping were the same except for feeding conditions. The test groups of animals received in addition to the main ration: I test group received hongurin zeolite in a dose of $0.7 \mathrm{~g} / \mathrm{kg}$ fresh weight from $10 \mathrm{~g}$ of Campendai salt in addition to the main ration; II test group received in other proportions hongurin zeolite in a dose of $0.7 \mathrm{~g} / \mathrm{kg}$ fresh weight from $200 \mathrm{~g}$ sapropel and $10 \mathrm{~g}$ of Campendai salt. The digestibility coefficients of feed nutrients consumed by the replacements were not unambiguous by groups. In terms of digestibility intensity, the control group of animals was behind the test groups in terms of DM by $0.87 \%$ and $2.73 \%$, organic matter by $1.03 \%$ and $3.17 \%$, protein by $0.01 \%$ and $0.29 \%$, fat by $0.21 \%$ and $0.43 \%$, fibre by $0.10 \%$ and $2.29 \%$ and nitrogen-free extractive substances by $1.98 \%$ and $4.36 \%$, respectively. Animals consuming non-traditional feed additives surpassed their peers from the control group by nitrogen assimilation by $0.23 \%$ and $3.10 \%$, calcium by $1.80 \%$ and $3.12 \%$, and phosphorus by $0.20 \%$ and $5.04 \%$. Thus, unconventional feed additives in cattle feeding contribute to better digestion and assimilation of minerals.

Keywords: cattle breeding; unconventional feeds; feeding; metabolism; productivity.

\section{Introduction}

It is known that intensification of the livestock breeding industry, realization of the animal potential as a result of this, high profitability of livestock production depends on the organization of the most complete and balanced feeding of animals (Hassan et al., 2016; Lombard et al., 2018; Mena et al., 2017).

Deficiency of minerals in diets causes metabolic disorders, reduces animal growth and development, and ultimately will contribute to the reduction of biological value of animal products. There is no ideal feed in nature that can fully meet all the nutritional and mineral needs of the body. Therefore, in the practice of feeding animals, a group of feeds is combined into diets. The missing nutrient and mineral elements are compensated from one feed to another (Abdelnour et al., 2018; Nikolaeva et al., 2015; Wu, 2020).

Scientists have scientifically substantiated the rationing of mineral substances in diets of farm animals (Kokorev et al., 2012; Menkova et al., 2014; Tolmacheva, 2009).

A wealth of experience has been accumulated and the necessity of regulation of trace elements in animal diets, such as iron, copper, zinc, iodine, manganese, molybdenum, cobalt, selenium and chromium has been convincingly proved (Papadomichelakis et al., 2018; Pappas et al., 2018). 
Various natural resources, in particular zeolites, sapropels and mineral salts, play an interesting solution for increasing the productivity of farm animals and birds (Ao et al., 2017; Đuričić et al., 2017; Stankevica et al., 2016; Valpotić et al., 2017).

The first tests of zeolite as a feed additive were conducted in 1965 in Japan. Zeolite was included in bird feeds. Researches have established that inclusion of 3.5-10\% of zeolites in mixed fodders promoted to decrease in consumption of forages, and also to increase intensity of growth and safety of birds (Makarenko, 2003). It should be noted that studies conducted by scientists in different places often give ambiguous similar results.

There are reports on the effectiveness of sapropels in feeding farm animals and birds. Extensive studies have been conducted on the territory of the Russian Federation, in the Amur region (Prostokishin et al., 2014), Tyumen region (Yarmots et al., 2018), in the Republic of Buryatia, and others (Tyrkheev, Lumbunov, 2015).

The work of Kerdyashov (2007) presents the author's analysis and research on the problems of feeding farm animals using non-traditional feed additives in their diets: zeolites, bentonite clay, filtration sludge, sapropel, betaine, protein, biotrin, confectionery waste, etc.).

On the territory of Yakutia, in the Suntarsky district, the Kempendya zeolite-bearing district, which is part of the Yenisei-Viliu zeolite province, is distinguished. The zeolite rocks are tiled, the sections are thin-plated, rather strong with uneven fracture. Greenish-blue tones prevail, rarely orange, yellowish, white. Gross chemical composition of zeolite rocks, \%: SiO2 - 68.04; A12O 12.60; Fe2O3 - 1.4; FeO - 0.29; $\mathrm{MgO}$ - 1.67; $\mathrm{CaO}$ - 2.54; $\mathrm{Na} 2 \mathrm{O}$ - 1.84; K2O-1.70. The zeolite rocks of the Khongurinskoye deposit have recently found wide application in such industries as industry, construction, medicine, agriculture and others. The use of zeolites in cattle feeding can fill a certain deficit of macro- and microelements in the diet of farm animals. Besides, zeolites have biologically active properties that have positive influence on animal health, normalize the course of physiological functions, sorbent harmful substances (Hassan et al., 2016).

At present, there is insufficient information on the influence of hongurin zeolite, sapropel and mineral salts on digestibility and metabolism indices of young cattle grown in Yakutia.

Purpose of research is to study the digestibility of fodder and metabolism Kholmogorskaya replacements in Yakutia conditions.

\section{Objectives of research are:}

- Feed digestibility during feeding of non-conventional fodder additives to Kholmogorskaya replacements; 
- Study of metabolism during feeding of non-conventional fodder additives to Kholmogorskaya replacements.

\section{Methods}

Experiments were carried out on the basis of Bagarakh agricultural enterprise of Yakutsk city suburban farm. The main purpose of the agricultural enterprise is to provide the population of Yakutsk with quality livestock products, namely whole milk and products of its processing: cream, sour cream, cottage cheese, kefir, yogurt, bull (national sour-milk drink of Yakutsk). The research was conducted within 270 days. The conditions for the experiments for the animals were identical, except for the inclusion of feed additives in the diet of the experimental groups. The control group of heifers of Kholmogorsk breed received the main feed; and the I experimental group additionally to the main feed received hongurin zeolite in a dose of $0.7 \mathrm{~g} / \mathrm{kg}$ fresh weight from $10 \mathrm{~g}$ of Campendai salt; the II experimental group received in other proportions hongurin zeolite in a dose of $0.7 \mathrm{~g} / \mathrm{kg}$ fresh weight from $200 \mathrm{~g}$ sapropel and $10 \mathrm{~g}$ of Campendai salt.

The conditions of all experimental animals and the grazing regime were the same for all groups. Repair young animals of Kholmogorsk breed were in the cattle house in spring time, the technology of keeping animals was group, unbound. In summer the experimental animals were in the pasture.

Chemical composition of putrid mud used in scientific and economic experiments is presented in Table 1.

Table 1. Chemical composition of putrid mud used in scientific and economic experiments

\begin{tabular}{clc} 
No & \multicolumn{1}{c}{ Indices } & $\begin{array}{c}\text { Rural locality Khatassy } \\
\text { (Yakutsk) }\end{array}$ \\
\hline 1 & Primitive moisture, $\%$ & 91.87 \\
\hline 2 & DM, \% & 7.83 \\
\hline 3 & Protein, \% & 0.71 \\
\hline 4 & Fat, $\%$ & 0.52 \\
\hline 5 & Fibre, $\%$ & 0.36 \\
\hline 6 & Nitrogen-free extractive substances, $\%$ & 0,48 \\
\hline 7 & Ash, $\%$ & 5.76 \\
\hline 8 & Ca, g & 0.194 \\
\hline 9 & P, g & 0.007 \\
\hline 10 & Carotin, g & 0.01
\end{tabular}

The experimental animals and agricultural birds were fed with recommendations (Kalashnikov et al., 2003), and daily diets of experimental animals and birds met the required norms. The chemical composition of feeds was studied. The rations of farm animals were made taking into account the detailed norms of feeding and were balanced on protein, carbohydrates, fats, dry, organic matter. 
Housing and feeding conditions were the same for all groups of animals and were in line with the technologies adopted on these farms.

The experimental data were statistically processed by Plokhinsky (1969). The reliability of the difference in indicators was estimated by the Student.

\section{Results and Discussions}

The scheme of feeding heifer calves of Kholmogorskaya and Red Steppe breed of cattle up to 6 months of age (live weight at the end of the period is $130 \mathrm{~kg}$ ) (calving in March) is presented in Table 2.

Table 2. Scheme of feeding heifer calves of Kholmogorskaya and Red Steppe breed of cattle up to 6 months of age (live weight at the end of the period is $130 \mathrm{~kg}$ ) (calving in March)

\begin{tabular}{|c|c|c|c|c|c|c|c|}
\hline \multicolumn{2}{|c|}{ Age } & \multirow{3}{*}{$\begin{array}{l}\text { Live weight at the end } \\
\text { of the period, } \mathrm{kg}\end{array}$} & \multicolumn{5}{|c|}{ A day's ration, $\mathrm{kg}$} \\
\hline \multirow{2}{*}{ Months } & \multirow{2}{*}{ Decades } & & \multicolumn{2}{|c|}{ Milk } & \multirow{2}{*}{$\begin{array}{c}\text { Dry } \\
\text { fodder }\end{array}$} & \multirow{2}{*}{ Grama grass } & \multirow{2}{*}{$\begin{array}{c}\text { Complete } \\
\text { feed }\end{array}$} \\
\hline & & & Whole & Skim & & & \\
\hline \multirow{3}{*}{ I } & 1 & \multirow{3}{*}{44} & 5 & \multirow{3}{*}{ accustomed } & & & - \\
\hline & 2 & & 5 & & & & - \\
\hline & 3 & & 5 & & & & accustomed \\
\hline During $\mathrm{t}$ & $1^{\text {st }}$ month & & 150 & & & & - \\
\hline \multirow{3}{*}{ II } & 4 & \multirow{3}{*}{61} & \multirow{3}{*}{3} & 3 & 0.4 & & 0.5 \\
\hline & 5 & & & 6 & 1.0 & & 0.9 \\
\hline & 6 & & & 6 & 1.0 & & 1.0 \\
\hline \multicolumn{3}{|c|}{ During the $2^{\text {nd }}$ month } & 30 & 150 & 24 & & 24 \\
\hline \multirow{3}{*}{ III } & 7 & \multirow{3}{*}{78} & & \multirow{3}{*}{$\begin{array}{l}3 \\
2\end{array}$} & 1.2 & & 1.0 \\
\hline & 8 & & & & 1.3 & & 1.0 \\
\hline & 9 & & & & 1.5 & & 1.0 \\
\hline \multicolumn{2}{|c|}{ During the $3^{\text {rd }}$ month } & & & 50 & 40.0 & & 30 \\
\hline \multirow{3}{*}{ IV } & 10 & \multirow{3}{*}{96} & & & & 6.0 & 1.2 \\
\hline & 11 & & & & & 8.0 & 1.2 \\
\hline & 12 & & & & & 8.0 & 1.2 \\
\hline \multicolumn{3}{|c|}{ During the $4^{\text {th }}$ month } & & & & 220 & 36 \\
\hline \multirow{3}{*}{$\mathrm{V}$} & 13 & \multirow{3}{*}{113} & & & & 10 & 1.0 \\
\hline & 14 & & & & & 10 & 1.0 \\
\hline & 15 & & & & & 11 & 1.0 \\
\hline \multicolumn{2}{|c|}{ During $5^{\text {th }}$ month } & & & & & 310 & 30 \\
\hline \multirow{3}{*}{ VI } & 16 & \multirow{3}{*}{130} & & & & 12 & 1.0 \\
\hline & 17 & & & & & 14 & 1.0 \\
\hline & 18 & & & & & 15 & 1.0 \\
\hline \multicolumn{3}{|c|}{ During $6^{\text {th }}$ month } & & & & 410 & 30 \\
\hline \multicolumn{3}{|c|}{ All within six months } & 180 & 200 & 64 & 940 & 141 \\
\hline & Energetic fe & unit $-557,7$ & 48.6 & 26.0 & 44.2 & 272.6 & 166.4 \\
\hline & igested pr & in, $\mathrm{kg}-58,3$ & 9.2 & 7.0 & 3.5 & 23.5 & 15.1 \\
\hline
\end{tabular}

Feeding schemes of replacements were balanced in terms of nutrients and met the required feeding standards (Kalashnikov et al., 2003; Wu, 2020). 
The study of digestibility and balance of nutrients in the diet of experimental repair heifers was carried out at the age of 12 months by placing 3 heads from each group under study. The experimental placement was carried out according to generally accepted zootechnical methods. Digestibility indices (DI) of nutritional substances are presented in Table 3.

Table 3. Digestibility index (DI) of nutritional substances of Kholmogorskaya replacements, $(\mathbf{M} \pm \mathbf{m}, \mathbf{n}=\mathbf{3})$

\begin{tabular}{|c|c|c|c|c|c|c|}
\hline Group of animals & DM & Organic substance & Protein & Fat & Fibre & $\begin{array}{c}\text { Nitrogen-free } \\
\text { extractive } \\
\text { substances }\end{array}$ \\
\hline \multicolumn{7}{|c|}{ Taken with feed, $g$} \\
\hline \multirow{2}{*}{ Control } & 6535.87 & 6076.31 & 599.74 & 224.93 & 1918.39 & 3333.25 \\
\hline & \pm 3.95 & \pm 3.88 & \pm 0.16 & \pm 0.20 & \pm 0.38 & \pm 3.19 \\
\hline \multirow{2}{*}{ I test group } & 6535.76 & 6076.17 & 599.67 & 224.93 & 1918.52 & 3333.06 \\
\hline & \pm 6.11 & \pm 5.80 & \pm 0.16 & \pm 0.08 & \pm 0.33 & \pm 5.42 \\
\hline \multirow{2}{*}{ II test group } & 6676.58 & 6200.26 & 603.82 & 229.34 & 1927.18 & 3439.92 \\
\hline & $\pm 6.43 * * *$ & $\pm 6.43 * * *$ & $\pm 0.00 * * *$ & $\pm 0.00 * * *$ & $\pm 1.60 * * *$ & $\pm 0.00 * * *$ \\
\hline \multicolumn{7}{|c|}{ Liberated with excrements, $g$} \\
\hline \multirow{2}{*}{ Control } & 1513.82 & 1276.24 & 168.40 & 52.93 & 374.22 & 680.69 \\
\hline & \pm 74.50 & \pm 64.30 & \pm 4.18 & \pm 3.95 & \pm 36.28 & \pm 28.62 \\
\hline \multirow{2}{*}{ I test group } & 1455.25 & 1212.18 & 169.45 & 53.96 & 376.24 & 612.52 \\
\hline & \pm 51.15 & \pm 56.23 & \pm 4.25 & \pm 2.98 & \pm 19.04 & \pm 60.21 \\
\hline \multirow{2}{*}{ II test group } & 1460.19 & 1200.19 & 169.55 & 55.40 & 338.20 & 637.04 \\
\hline & \pm 98.68 & \pm 95.25 & \pm 7.68 & \pm 6.57 & \pm 16.62 & \pm 106.95 \\
\hline \multicolumn{7}{|c|}{ Digested, g } \\
\hline \multirow{2}{*}{ Control } & 5022.05 & 4800.07 & 431.33 & 172.01 & 1544.17 & 2652.56 \\
\hline & \pm 78.19 & \pm 68.17 & \pm 4.33 & \pm 4.13 & \pm 36.56 & \pm 31.51 \\
\hline \multirow{2}{*}{ I test group } & 5080.52 & 4864.00 & 430.22 & 170.96 & 1542.28 & 2720.53 \\
\hline & \pm 47.05 & \pm 52.45 & \pm 4.11 & \pm 3.05 & \pm 18.85 & \pm 57.99 \\
\hline \multirow{2}{*}{ II test group } & 5216.39 & 5000.07 & 434.27 & 173.94 & 1588.98 & 2802.88 \\
\hline & \pm 98.68 & \pm 95.25 & \pm 7.68 & \pm 6.57 & \pm 16.62 & \pm 106.95 \\
\hline \multicolumn{7}{|c|}{ DI, \% } \\
\hline \multirow{2}{*}{ Control } & 75.40 & 77.47 & 71.63 & 75.41 & 80.16 & 77.12 \\
\hline & \pm 1.17 & \pm 1.10 & \pm 0.72 & \pm 1.81 & \pm 1.90 & \pm 0.92 \\
\hline \multirow{2}{*}{ I test group } & 76.27 & 78.50 & 71.64 & 75.62 & 80.26 & 79.10 \\
\hline & \pm 0.71 & \pm 0.85 & \pm 0.68 & \pm 1.34 & \pm 0.98 & \pm 1.69 \\
\hline \multirow{2}{*}{ II test group } & 78.13 & 80.64 & 71.92 & 75.84 & 82.45 & 81.48 \\
\hline & \pm 1.48 & \pm 1.54 & \pm 1.27 & \pm 2.86 & \pm 0.86 & \pm 3.11 \\
\hline
\end{tabular}

Nota bene: $* * * \mathrm{P}>0.999$

The digestibility index (DI) of nutritional substances of Kholmogorskaya replacements was different by groups. The control group of repair heifers has yielded on indicators to experimental groups on: DM on $0.87 \%$ and $2.73 \%$, organic matter on $1.03 \%$ and $3.17 \%$, protein on $0.01 \%$ and $0.29 \%$, fat on $0.21 \%$ and $0.43 \%$, fibre on $0.10 \%$ and $2.29 \%$ and nitrogen-free extractive substances on $1.98 \%$ and $4.36 \%$ (difference on indicators is not authentic).

Increase of nutrients digestibility factor of a diet at experimental groups of Kholmogorskaya replacements is explained by action of local nonconventional feed additives on intensity of digestion and a metabolism. 
Balance experiment data show that nitrogen balance in all groups of experimental Kholmogorskaya replacements was positive, data are presented in Table 4.

Table 4. Nitrogen balance in experimental replacements, $(M \pm m, n=3)$

\begin{tabular}{lccc}
\multicolumn{1}{c}{ Indices } & \multicolumn{3}{c}{ Groups of animals } \\
\cline { 2 - 4 } & Control & I test group & II test group \\
\hline Taken with feed, $\mathrm{g}$ & $99.79 \pm 0.03$ & $99.78 \pm 0.03$ & $100.47 \pm 0.00^{* * *}$ \\
\hline Liberated with excrements, $\mathrm{g}$ & $28.02 \pm 0,70$ & $28.19 \pm 0.71$ & $28.26 \pm 0.62$ \\
\hline Digested, $\mathrm{g}$ & $71.77 \pm 0.72$ & $71.58 \pm 0.68$ & $72.21 \pm 0.62$ \\
\hline Liberated with stale, $\mathrm{g}$ & $36.24 \pm 4.10$ & $36.07 \pm 4.71$ & $+35.68 \pm 1.30$ \\
\hline Balance, $(+,-)$ & $+35.43 \pm 4.39$ & $+35.51 \pm 4.76$ & $+36.53 \pm 1.92$ \\
\hline Used: & & & $36.36 \pm 1.91$ \\
\hline from taken, $\%$ & $35.60 \pm 4.39$ & $35.59 \pm 4.78$ & $50.60 \pm 2.25$
\end{tabular}

Nota bene: $* * * \mathrm{P}>0.999$

Groups of experimental Kholmogorskaya replacements were superior to their peers from the control group in nitrogen assimilation index by $0.23 \%$ and $3.10 \%$.

Thus, the research data show that inclusion of local unconventional feed additives into the diet of grown Kholmogorskaya replacements improves nitrogen assimilation. The optimal dose with the best result was chongurin in the dose of $0.7 \mathrm{~g}$ per $\mathrm{kg}$ of live weight with $200 \mathrm{~g}$ of sapropel and $10 \mathrm{~g}$ of Campendai salt.

In addition to determining nitrogen levels, calcium and phosphorus levels are important indicators that determine metabolism in animals.

Calcium balance and its use by Kholmogorskaya replacements is presented in Table 5.

Table 5. Calcium balance in experimental replacements, $(M \pm m, n=3)$

\begin{tabular}{lccc}
\multicolumn{1}{c}{ Indices } & \multicolumn{2}{c}{ Groups of animals } \\
\cline { 2 - 4 } & Control & I test group & II test group \\
\hline Taken with feed, $\mathrm{g}$ & $55.57 \pm 0.02$ & $55.53 \pm 0.06$ & $56.40 \pm 0.00 * * *$ \\
\hline Liberated with excrements, $\mathrm{g}$ & $31.06 \pm 3.53$ & $30.59 \pm 2.58$ & $31.14 \pm 1.78$ \\
\hline Liberated with stale, $\mathrm{g}$ & $0.13 \pm 0.01$ & $0.13 \pm 0.03$ & $0.13 \pm 0.00$ \\
\hline Total liberation, $\mathrm{g}$ & $31.19 \pm 3.54$ & $30.72 \pm 4.46$ & $31.26 \pm 1.78$ \\
\hline Balance $(+),(-)$ & $+24.38 \pm 3.56$ & $+24.82 \pm 2.54$ & $+25.14 \pm 1.78$ \\
\hline Used, \% from taken & $43.86 \pm 6.39$ & $44.69 \pm 4.61$ & $44.58 \pm 3.16$
\end{tabular}

Nota bene: $* * * \mathrm{P}>0.999$

Experimental heifers outperformed their counterparts in the control group by $1.80 \%$ and $3.12 \%$ calcium. The balance of phosphorus for the experimental heifers is presented in Table 6 .

Table 6. Phosphorus balance in experimental replacements, $(M \pm m, n=3)$

\begin{tabular}{lccc}
\multicolumn{1}{c}{ Indices } & \multicolumn{3}{c}{ Groups of animals } \\
\cline { 2 - 4 } & Control & I test group & II test group \\
\hline Taken with feed, g & $24.77 \pm 0.01$ & $24.77 \pm 0.03$ & $25.02 \pm 0.00^{* * *}$ \\
\hline Liberated with excrements, g & $10.96 \pm 1.46$ & $10.98 \pm 2.29$ & $10.83 \pm 1.15$
\end{tabular}




\begin{tabular}{lccc} 
Liberated with stale, $\mathrm{g}$ & $3.88 \pm 0.32$ & $3.84 \pm 0.35$ & $3.77 \pm 0.18$ \\
\hline Total liberation, $\mathrm{g}$ & $14.84 \pm 1.46$ & $14.82 \pm 1.94$ & $14.59 \pm 1.07$ \\
\hline Balance $(+),(-)$ & $+9.93 \pm 1.46$ & $+9.95 \pm 1.93$ & $+10.43 \pm 1.07$ \\
\hline Used, \% from taken & $40.09 \pm 5.89$ & $40.16 \pm 7.83$ & $41.67 \pm 4.27$
\end{tabular}

Nota bene: $* * * \mathrm{P}>0.999$

Experimental replacements outperformed their counterparts from the control group by $0.20 \%$ and $5.04 \%$ phosphorus.

Thus, Kholmogorskaya replacements of experimental groups, who received local unconventional feed supplements, used calcium and phosphorus better.

\section{Conclusion}

Inclusion of local unconventional fodder additives in the daily diet of Kholmogorskaya replacements helps to accelerate the process of digestion, facilitates the hydrolysis of feed nutrients, and stimulates the absorption of the final products of their hydrolysis. The coefficient of digestibility of nutrients in experimental groups of heifers was higher in comparison with peers from the control group: DM by $0.87 \%$ and $2.73 \%$, organic matter by $1.03 \%$ and $3.17 \%$, protein by $0.01 \%$ and $0.29 \%$, fat by $0.21 \%$ and $0.43 \%$, fibre by $0.10 \%$ and $2.29 \%$ and nitrogen-free extractive substances by $1.98 \%$ and $4.36 \%$.

Groups of experimental Kholmogorskaya replacements surpassed their counterparts from the control group on metabolism, respectively, in nitrogen $0.23 \%$ and $3.10 \%$, calcium $1.80 \%$ and $3.12 \%$ and phosphorus $0.20 \%$ and $5.04 \%$.

Thus, the use of hongurin and putrid mud as a feed additive helps to normalize metabolism and physiological parameters of animals. It allowed to increase the productivity of animals. It helped to reduce costs per unit of production.

\section{References}

Abdelnour, S.A., Abd El-Hack, M.E., Swelum, A.A., Perillo, A., Losacco, C. (2018). The vital roles of boron in animal health and production: A comprehensive review. Journal of Trace Elements in Medicine and Biology, 50, 296-304. DOI: 10.1016/j.jtemb.2018.07.018

Ao, T., Macalintal, L.M., Paul, M.A., Pescatore, A.J., Delles, R.M., Cantor, A.H., et al. (2017). Effects of dietary supplementation of organic minerals on the performance of broiler chicks fed oxidised soybean oil. Journal of Applied Animal Nutrition, 5. DOI: 10.1017/jan.2017.10

Đuričić, D. et al. (2017). Dietary zeolite clinoptilolite supplementation influences chemical composition of milk and udder health in dairy cows. Veterinarska stanica: znanstvenostručni veterinarski časopis, 48(4), 257-265. 
Hassan, T.M., Abdel-Fattah, F.A., Farid, A.S., Kamel, E.R. (2016). Effect of feeding guava waste on growth performance, diet digestibility, carcass characteristics and production profitability of ossimi lambs. Egyptian Journal of Nutrition and Feeds, 19(3), 461-472.

Kalashnikov, A.P. (2003). Norms and diets for feeding farm animals. Reference book. 3rd edition revised and supplemented. Moscow: Russian Agricultural Edition.

Kerdyashov, N.N. (2007). Feeding of the agricultural animals with the use of the local unconventional feed additives: monograph. Penza.

Kokorev, V.A., Salaev, B.K., Arilov, A.N., Natyrov, A.K. (2012). Mineral feeding of the young indigenous species in the conditions of the arid territories of the south of Russia. Vestnik of Kalmyk University, 1(13), 22-27.

Lombard, W.A., Maré, F.A., Jordaan, H. (2018). The influence of animal traits on feedlot profitability of Santa Gertrudis cattle in South Africa. Agrekon, 57(2), 101-107. DOI: $10.1080 / 03031853.2018 .1477606$

Makarenko, L.Y. (2003). Efficiency of Pegasus zeolite use in cattle feeding: dissertation for the degree of Doctor of Agricultural Sciences. Kemerovo.

Mena, Y., Gutierrez-Peña, R., Ruiz, F.A., Delgado-Pertíñez, M. (2017). Can dairy goat farms in mountain areas reach a satisfactory level of profitability without intensification? A case study in Andalusia (Spain). Agroecology and Sustainable Food Systems, 41(6), 614-634. DOI: $10.1080 / 21683565.2017 .1320620$

Menkova, A.A., Andreev, A.I., Chikunova, V.I. (2014). Influence of a different mineral nutrition level on the functional adrenal gland morphology of the repair heifers. Vestnik of Ulyanovsk state agricultural academy, 2(26), 114-118.

Nikolaeva, N.A., Pankratov, V.V., Chernogradskaya, N.M., Grigoriev, M.F. (2015). The use of feed additives in the diet of cows and young cattle in Yakutia. Biosciences Biotechnology Research Asia, 12(2), 1651-1657.

Papadomichelakis, G., Zoidis, E., Pappas, A.C., Danezis, G., Georgiou, C.A., Fegeros, K. (2018). Dietary organic selenium addition and accumulation of toxic and essential trace elements in liver and meat of growing rabbits. Meat science, 145, 383-388.

Pappas, A.C., Godlewska, K., Surai, P.F. (2018). Dietary Food and Feed Supplements with Trace Elements. Recent Advances in Trace Elements, 421.

Plokhinskiy, N.A. (1969). Biometrics manual for zootechnicians. Moscow: Kolossus. 
Prostokishin, A.S., Tuaeva, E.V., Ryzhkov, V.A., Babukhadiya, K.R. (2014). Use of a sapropel and Japanese kelp feed for animals and birds. Zootekhniya, 3, 21-22.

Stankevica, K., Vincevica-Gaile, Z., Klavins, M. (2016). Freshwater sapropel (gyttja): its description, properties and opportunities of use in contemporary agriculture. Agronomy Research, 14(3), 929-947.

Tolmacheva, N.V. (2009). Methodology and principles of hygienic rationing of the macro- and microelements balance in the drinking water and food ration. Kazanskiy medical journal, 90(6), 866-870.

Tyrkheev, A.P., Lumbunov, S.G. (2015). Sapropelic feed additive influence on the sow productivity. Bulletin of the Buryat State Agricultural Academy, 4(41), 83-86.

Valpotić, H., Gračner, D., Turk, R., Đuričić, D., Vince, S., Folnožić, I., et al. (2017). Zeolite clinoptilolite nanoporous feed additive for animals of veterinary importance: potentials and limitations. Periodicum biologorum, 119(3), 159-172.

Wu, G. (2020). Management of metabolic disorders (including metabolic diseases) in ruminant and nonruminant animals. Animal Agriculture, 471-491.

Yarmots, G.A., Smyshlyaeva, M.O., Belen'kaya, A.E. (2018). Sapropel use in animal husbandry. Collection of articles of II All-Russian (national) scientific-practical conference "Modern scientific-practical solutions in agroindustrial complex", 107-110. 